\title{
Virus Coat Protein Transgenic Papaya Provides Practical Control of Papaya ringspot virus in Hawaii
}

\author{
S. A. Ferreira and K. Y. Pitz, Plant and Environmental Protection Sciences, and R. Manshardt, Tropical Plant and \\ Soil Sciences, University of Hawaii; F. Zee and M. Fitch, USDA-ARS Pacific Basin Research Center; and \\ D. Gonsalves, Department of Plant Pathology, NYS Agricultural Research Station, Cornell University
}

\begin{abstract}
Ferreira, S. A., Pitz, K. Y., Manshardt, R., Zee, F., Fitch, M., and Gonsalves, D. 2002. Virus coat protein transgenic papaya provides practical control of Papaya ringspot virus in Hawaii. Plant Dis. 86:101-105.

Since 1992, Papaya ringspot virus (PRSV) destroyed nearly all of the papaya hectarage in the Puna district of Hawaii, where $95 \%$ of Hawaii's papayas are grown. Two field trials to evaluate transgenic resistance (TR) were established in Puna in October 1995. One trial included the following: SunUp, a newly named homozygous transformant of Sunset; Rainbow, a hybrid of SunUp, the nontransgenic Kapoho cultivar widely grown in Puna, and 63-1, another segregating transgenic line of Sunset. The second trial was a 0.4-ha block of Rainbow, simulating a nearcommercial planting. Both trials were installed within a matrix of Sunrise, a PRSV-susceptible sibling line of Sunset. The matrix served to contain and trace pollen flow from TR plants, and as a secondary inoculum source. Virus infection was first observed 3.5 months after planting. At a year, $100 \%$ of the non-TR control and $91 \%$ of the matrix plants were infected, while PRSV infection was not observed on any of the TR plants. Fruit production data of SunUp and Rainbow show that yields were at least three times higher than the industry average, while maintaining percent soluble solids above the minimum of $11 \%$ required for commercial fruit. These data suggest that transgenic SunUp and Rainbow, homozygous and hemizygous for the coat protein transgene, respectively, offer a good solution to the PRSV problem in Hawaii.
\end{abstract}

Additional keywords: coat protein transgenic resistance

In May 1992, Papaya ringspot virus (PRSV), a Potyvirus, was discovered in the Puna district of the island of Hawaii, where over $95 \%$ of Hawaii's papayas are produced. Initially discovered in a 49-ha parcel, PRSV spread quickly through the Puna region. Within 3 years, over 1,000 ha, or nearly $100 \%$ of the plants in the Puna area, were severely affected. Papaya production in Hawaii declined from about 48 million pounds, just prior to the PRSV outbreak in Puna, to about 30.9 million pounds of fruit in 1997 (11). Thus, PRSV threatened to eliminate Hawaii's second most important fruit crop $(3,6)$, valued at about $\$ 15$ to $\$ 18$ million annually at the farm gate (11).

Coincidentally, in April 1992, a field trial was established with $\mathrm{R}_{0}$ plants of transgenic papaya line 55-1 that showed

Corresponding author: S. A. Ferreira

E-mail: stephenf@hawaii.edu

This paper is a contribution from the College of Tropical Agriculture and Human Resources, Journal Series no. 4574

Accepted for publication 28 August 2001.

Publication no. D-2001-1217-04R

(C) 2002 The American Phytopathological Society resistance to a Hawaiian isolate of PRSV in greenhouse experiments (4). Results of the 1992 field trial showed that $R_{0}$ plants of line 55-1 were resistant to PRSV under field conditions and that fruit quality was good (9). These results showed that use of transgenic resistance (TR) might be a practical way to control PRSV in Hawaii and to help save the papaya industry. Southern blot analysis showed that line 55-1 contains a single insert of the coat protein $(\mathrm{CP})$ gene of the mild PRSV isolate HA 5-1 $(6,8,15,16)$, which was originally developed by transforming the red-flesh Hawaiian solo papaya cultivar Sunset $(4,10)$. Two cultivars, designated Rainbow (Fig. 1A) and SunUp (Fig. 1B), were subsequently developed from line 55-1 (10). SunUp is line 55-1, which is homozygous for the $\mathrm{CP}$ gene, while Rainbow is an $F_{1}$ hybrid of SunUp and Kapoho. The latter is a yellowflesh Hawaiian papaya that is by far the most widely planted cultivar in Puna (12). The development of Rainbow was significant because papaya consumers prefer the yellow-flesh Hawaiian papaya to the redflesh type.

The epidemic of PRSV in Puna and potential loss of the Hawaiian papaya industry made it urgent to test SunUp and particularly Rainbow under field conditions in
Puna. In October 1995, a field trial of SunUp and Rainbow was established in Puna to determine if the transgenic resistance would hold up to the severe PRSV pressure in Puna and to evaluate the cultivars for horticultural performance. We show that both cultivars are highly resistant to PRSV and possess acceptable commercial qualities.

\section{MATERIALS AND METHODS}

Test plants. SunUp was derived from the $\mathrm{R}_{0}$ papaya transformant designated transgenic line 55-1. This line was developed by transforming nontransgenic Sunset (4) with the CP gene of PRSV HA 5-1, a mild nitrous acid mutant of PRSV HA from Hawaii (16). SunUp is homozygous for the single $\mathrm{CP}$ transgene insert $(6,9)$. Rainbow is an $F_{1}$ hybrid of SunUp and the nontransgenic Kapoho. The nontransgenic controls were Sunset, Kapoho, and $\mathrm{F}_{1}$ hybrid of Sunset and Kapoho (the nontransgenic Rainbow equivalent). Sunrise was used in the border rows and was also analyzed for PRSV infection and fruit yield.

Field test description and experimental design. The field test was established in October 1995 on a grower's farm in the Kapoho area of Puna under a permit from APHIS (Animal and Plant Health Inspection Service). Transplant seedlings of the treatment cultivars were produced on the farm in an unscreened shade house, and were transplanted when about 3 months old. At least three plants were established in each planting hole, and were thinned to a single hermaphrodite plant when flowering occurred 5 to 6 months later.

Plant spacing was $3.4 \mathrm{~m}$ between rows and $1.7 \mathrm{~m}$ between plants in a row. Treatment plots in this comparative test consisted of two rows of 8 plants or 16 plants per plot, planted in a randomized complete block design with four replications. Treatment blocks were planted within a matrix of nontransgenic Sunrise, the susceptible cultivar grown by the cooperator. This matrix consisted of two papaya rows along the length of the test area, and varied from 6 to 18 plants along the ends of the test area. This occurred because the field was not rectangular and because plant spacing within a row was not precise. The matrix would enable us to estimate PRSV pro- 
gress and yield of the nontransgenic, susceptible papaya cultivar.

In addition to the replicated test, a 0.4ha block of Rainbow established within a matrix of nontransgenic Sunrise plants also adjacent to the replicated plots. The purpose of this planting was to obtain fruit that could be handled commercially, or processed through a packing plant that involved the sorting and grading of fruit followed by the vapor heat treatment of $47.8^{\circ} \mathrm{C}$ for a minimum of $4 \mathrm{~h}$ required of all fruit exported from Hawaii for fruit fly control (1).

The field trial was maintained by the cooperating grower, using his usual practices for fertilization and control of weeds, insects, and diseases. Other than problems caused by broad mites and leaf edge roller mites, and root rot caused by Phytophthora palmivora, despite the regular use of insecticides and fungicides available for papaya, no unusual disease, pest, or cultural problems were experienced.

Virus source. The primary virus source was PRSV-infected trees of an abandoned papaya orchard about $24 \mathrm{~m}$ away and upwind of the prevailing tradewinds of the test site. The susceptible matrix of Sunrise plants also served as secondary inoculum once PRSV became established in the trial. Also, 2 months after initial infection was observed in border rows, every fifth plant of the matrix rows that was not infected naturally was inoculated mechanically with PRSV. In April 1996, when the transgenic seedlings began to flower and could serve as a pollen source, the adjacent abandoned field was destroyed to minimize transgene escape from the test site. The nearest location of other papaya fields, all but one of which had been abandoned commercially, was approximately $0.4 \mathrm{~km}$ from the test site.

Virus incidence in test plots. Test plants, including those in the matrix, were visually monitored for PRSV symptoms at monthly intervals. Symptoms included water-soaked streaking on leaf petioles, chlorotic mosaic and veinclearing on leaves, and leaf distortion and shoestringing of leaves and ringspots on fruit. Samples with indefinite symptoms were judged as questionable and usually confirmed visually at the subsequent observation period. Enzyme-linked immunosorbent assays (ELISA) with antiserum to PRSV HA were periodically used to confirm visual ratings of PRSV $(2,7)$.

Yield and field performance. About 15 months after planting and after an initial harvest period of about 5 months, fruit yield and quality data were obtained at bimonthly intervals. Fruit was graded into two marketable grades, A and B, and an unmarketable grade, C. Grade A fruit consisted of fruit with less than $10 \%$ of the surface blemished or distorted. Grade B fruit had blemish and distortion levels up to $20 \%$ and weighed less than $340 \mathrm{~g}$ or more than $794 \mathrm{~g}$, but was still of commercial value. Grade $\mathrm{C}$ fruit were culls that were too small or too severely blemished or distorted to be sold. Marketable yield for each harvest period was expressed on weight $(\mathrm{kg})$ per hectare basis.

Fruit quality was assessed by estimating sugar content by refractometer soluble solids percent (brix) of five fruit randomly obtained from the A and $\mathrm{B}$ grades of fruit from each plot. Culled or grade $\mathrm{C}$ fruit was not measured. Fruit were also assessed for ringspot incidence by estimating the fruit surface area blemished by PRSV ringspots.

Fruit quality and yield data from the 0.40-ha block of Rainbow were obtained bimonthly by harvesting the block completely and taking all fruit to a commercial packinghouse where total fruit weight was measured before sorting and grading. The fruit was washed and graded commercially, and yields were obtained from each of the grade levels. Following this sorting process, a bin of the fruit (approximately 408 $\mathrm{kg}$ ) was subjected to the commercial vapor heat treatment (1). Yields were obtained every 2 months, and all fruit were washed and processed through a commercial packing operation to obtain weight of marketable and culled Rainbow fruit. Following vapor heat treatment, a random 100-fruit sample was removed, and fruit softened or damaged during vapor heat treatment were discarded. Based on this final discard rate, pack out or marketable fruit production was calculated and expressed on a weekly basis. Fruit refractometer solids (\%) were determined after vapor heat treatment. A comparison was made to Kapoho fruit obtained from a commercial packinghouse because Kapoho could not be successfully produced at our test site.

\section{RESULTS}

SunUp and Rainbow resistance to PRSV. Disease progress curves for PRSV in the replicated plots and the 0.40-ha block of Rainbow are given in Figures 2 and 3. PRSV infection occurred about 3.5 months after transplanting and was observed first in some of the susceptible Sunrise plants of the matrix most adjacent and downwind from the abandoned papaya field serving as the primary inoculum source. One year after planting, about 8 months after initial infection, and after 3 months of harvest, all of the matrix and control plants were infected. In the replicated portion of the test, none of the SunUp or Rainbow plants became infected by PRSV during the 2.5-year period of the trial. However, in the 0.40-ha block of Rainbow intended to simulate commercial production, three transgenic Rainbow plants were infected. They were observed about 4 months after transplanting and represented about $0.06 \%$ (3 of approximately 5,000 plants) of the plants in the Rainbow block. The plant population was high at this time because the grower had not yet sexed and thinned his field to a single hermaphrodite tree per planting hole to give the 1,730 trees per hectare typical of an older papaya orchard.
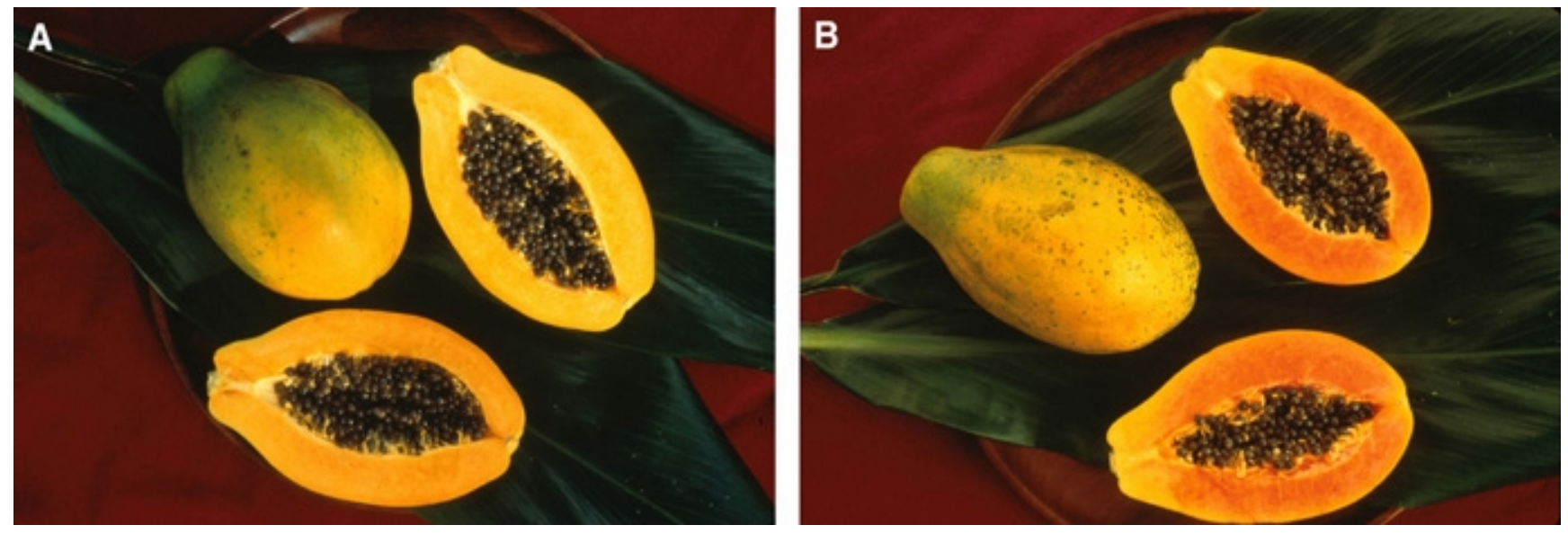

Fig. 1. Ripe fruit of the coat protein transgenic, yellow-flesh papaya cultivar Rainbow, A, and of the red-flesh transgenic cultivar SunUp, B. Rainbow is hemizygous for the coat protein transgene of the Papaya ringspot virus (PRSV) mild strain, HA 5-1, and is the $\mathrm{F}_{1}$ hybrid of SunUp and the nontransgenic cultivar Kapoho. 


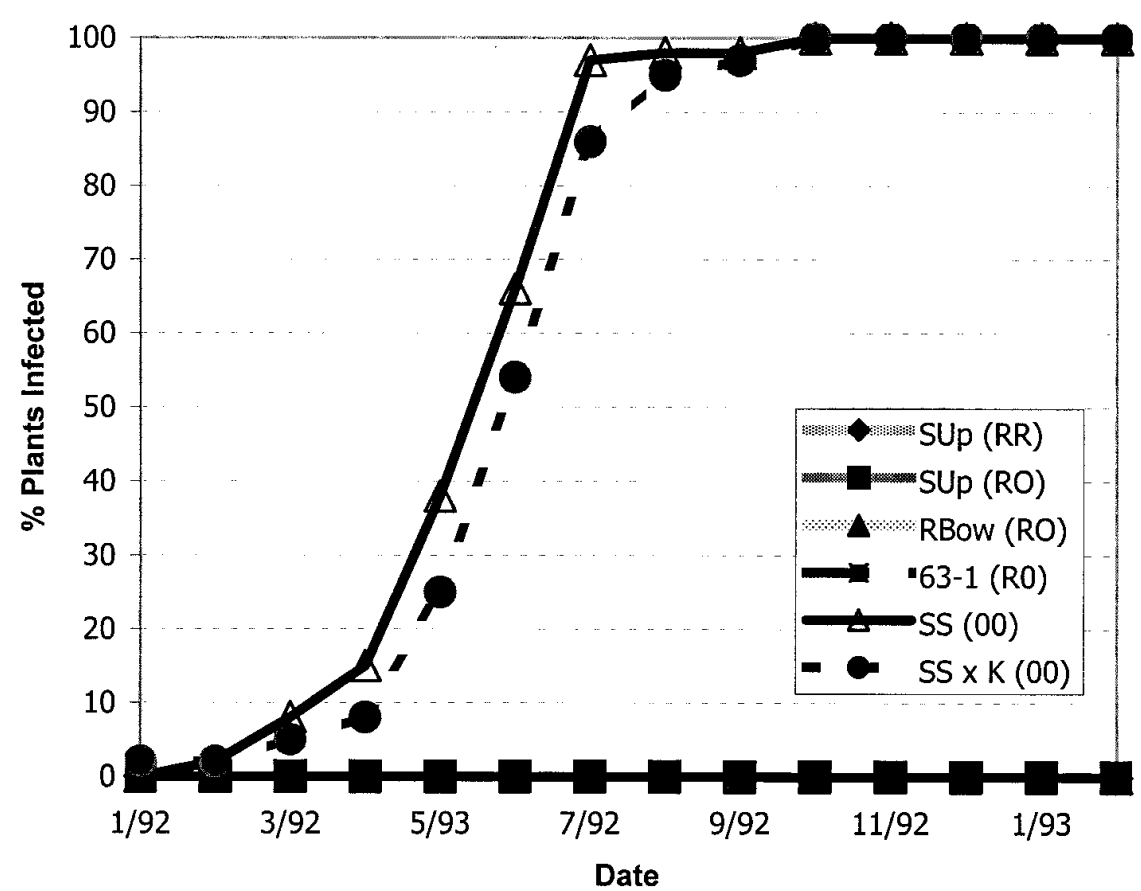

Fig. 2. Disease progress curves for transgenic and nontransgenic papaya cultivars in the Kapoho field trial. Only three plants in the 0.4-ha Rainbow block and none of the transgenic plants of the replicated trial became infected with Papaya ringspot virus (PRSV). Subsequent inoculations of the virus isolates from the three infected Rainbow plants to Rainbow and SunUp plants were negative, indicating that a PRSV strain capable of overcoming the coat protein transgene in Rainbow or SunUp had not developed.
The possibility that these Rainbow plants were infected with strains of PRSV that could readily infect Rainbow was tested by using inoculum from the three infected plants to mechanically inoculate Rainbow, SunUp, and Sunrise (susceptible) seedlings. None of the inoculated Rainbow or SunUp seedlings developed symptoms visually, nor were they positive by ELISA, while all of the susceptible Sunrise seedlings became infected.

In addition to these three plants that were infected at approximately 4 months, PRSV was observed on Rainbow plants more than 20 months old on lateral shoots that develop on the trunks of older papaya plants. On these trees, virus symptoms, confirmed by ELISA, occurred only on side shoots and never on leaves of the main canopy. Incidence of infected side shoots varied between observation periods, but the incidence of orchard trees with at least one infected sideshoot was always less than $1.3 \%$. As was the case with the original infected Rainbow plants, PRSV sideshoot isolates did not overcome the resistance of Rainbow test seedlings.

Fruit yield and quality of transgenic cultivars. Fruit yield and quality of transgenic Rainbow and nontransgenic Sunrise fruit from the near-commercial, 0.40-ha block are given in Figures 4 and 5. At each
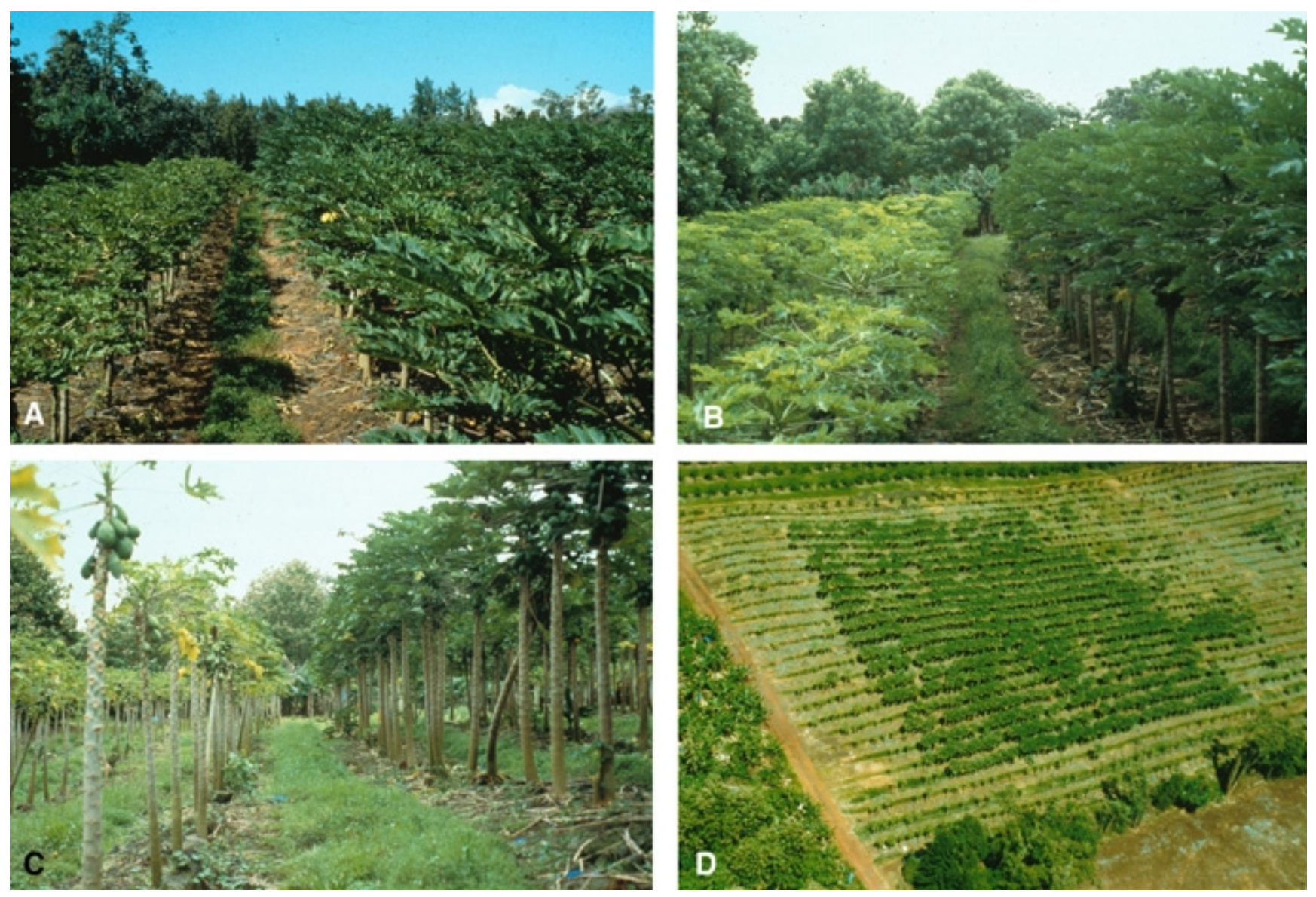

Fig. 3. Visual disease progress in the susceptible papaya matrix plants of Sunrise in the 0.4-ha Rainbow block at A, 9 months, B, 18 months, and $\mathbf{C}, 23$ months after transplanting. Aerial photograph of the Rainbow block, D, 28 months after transplanting, at which time the severely Papaya ringspot virus (PRSV)-infected matrix plants (Sunrise) are clearly distinguishable from the resistant transgenic Rainbow plants by PRSV infection. 


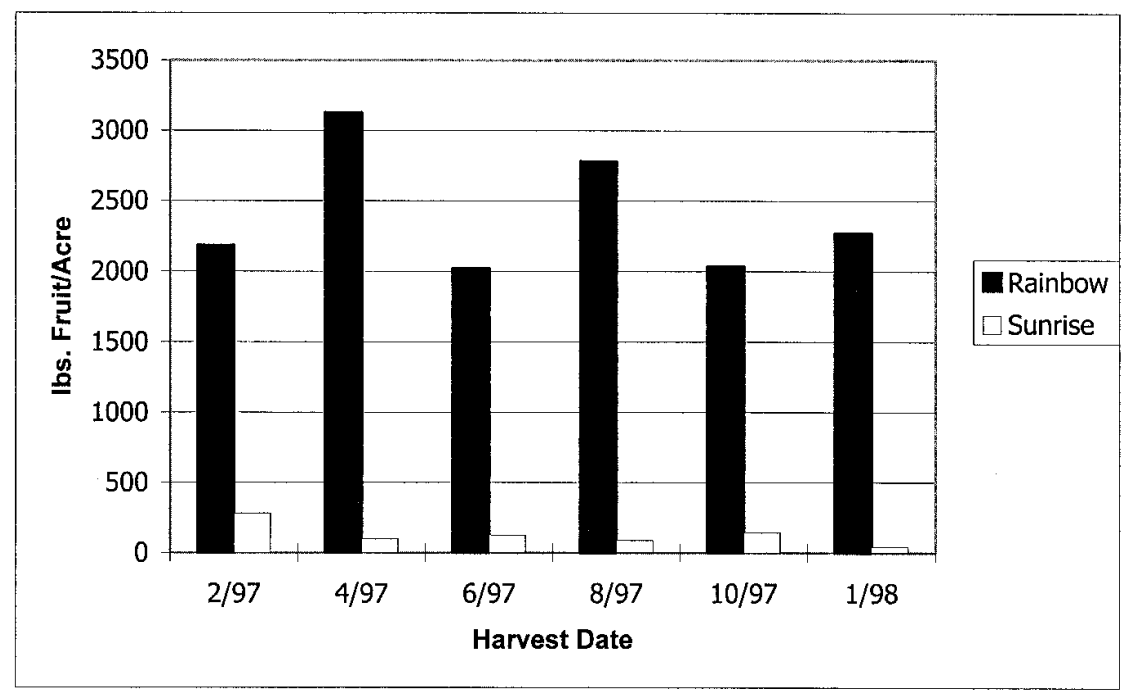

Fig. 4. Comparison of bimonthly fruit yield of the hemizygous transgenic Rainbow cultivar of papaya in the 0.4 -ha block and the Sunrise cultivar from the surrounding susceptible matrix 17 to 28 months after planting.

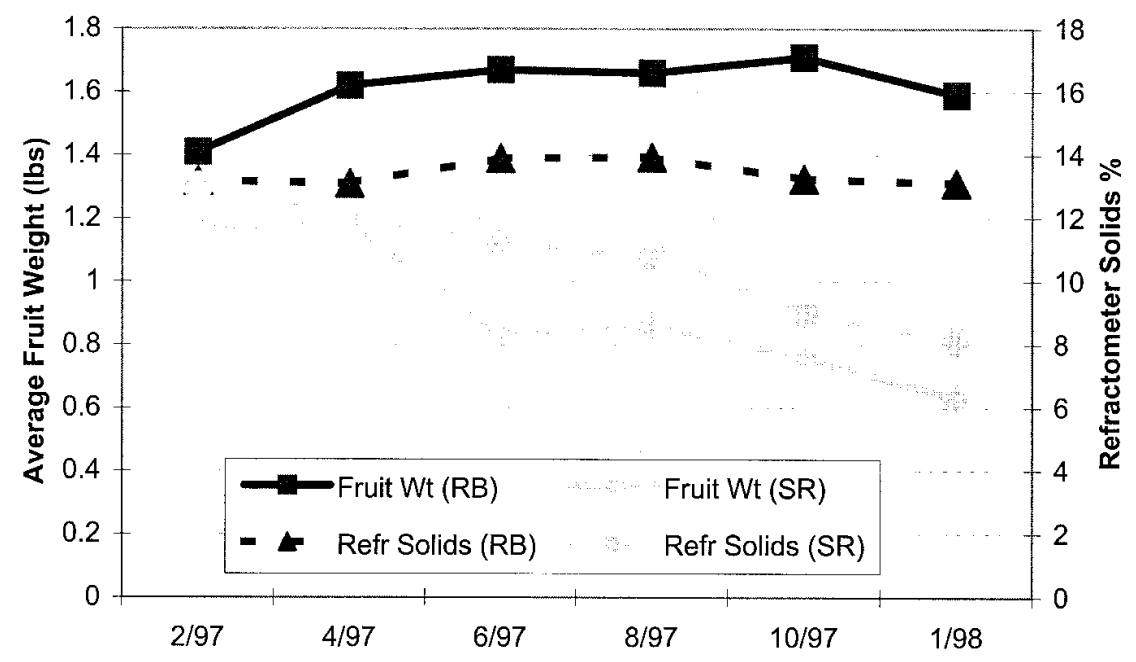

Fig. 5. Comparison of individual fruit weight and refractometer solids (\%) of Rainbow and Sunrise papaya fruit from the 0.4 -ha block 17 to 28 months after planting.

of the harvest periods, Rainbow yields were over $2,242 \mathrm{~kg} / \mathrm{ha}$ or over 126 tonnes of marketable fruit per hectare annually. This did not decline over the cropping cycle and was about 3.5 times the industry average of about 35.2 tonnes/ha during the 5-year period, 1988 to 1992 , immediately prior to the discovery of PRSV in Puna. For the susceptible Sunrise matrix plants, annualized yields were initially $419 \mathrm{~kg}$ of fruit per hectare and declined to less than $56 \mathrm{~kg} / \mathrm{ha}$ after 1.5 years of harvest. In practice, most growers would have abandoned harvest of Sunrise after about 6 months of harvest and would have experienced financial loss for that block.

Similarly, average fruit weight of Rainbow ranged from 635 to $771 \mathrm{~g}$, and refractometer solids varied during the harvest period but was always higher than the minimum standard of $11 \%$ required of grade A fruit. For Sunrise, both fruit
Sunset hybrid and Sunset, yields were acceptable initially but declined from about $2,242 \mathrm{~kg} / \mathrm{ha}$ to about $112 \mathrm{~kg} / \mathrm{ha}$ after 6 months.

Fruit quality data, based on average fruit weight and refractometer solids (\%), varied during the harvest cycle but never declined to unacceptable levels for the transgenic lines. For the susceptible controls lines, however, average fruit weight and refractometer solids of marketable grade A and B fruit were commercially acceptable, but the fruit yield indicated in Table 1 was economically unacceptable.

\section{DISCUSSION}

The results of this large-scale field evaluation of PRSV-resistant transgenic papayas was gratifying. It was impressive since the technology performed well in terms of PRSV control and because the strategy of using an $F_{1}$ hybrid with hemizygous resistance proved to be practical. Further, based on these results, the Papaya Administrative Committee, the industry marketing order group, obtained the necessary licenses to commercialize the underlying technologies utilized in developing the transgenic papayas. In May 1998, both Rainbow and SunUp were released to growers. By May 1999, over 607 ha (approximately $50 \%$ of the total commercial papaya-growing area) of transgenic papaya had been planted. These fruit are now in U.S. retail markets.

We previously demonstrated that $R_{1}$ plants of line 55-1 (parent of SunUp) that are hemizygous for the CP gene of HA 5-1 were resistant to PRSV from Hawaii, but largely susceptible to PRSV outside of Hawaii $(6,15)$. Thus, the three Rainbow plants that became infected in the field caused us to be concerned about the presence of PRSV strains in Hawaii that could overcome the coat protein transgenic resistance. Our back inoculations did not support the contention that transgenic resistance-breaking strains of PRSV occurred in Puna. Instead, recent data suggest that Rainbow seedlings less than 8 weeks old are susceptible to Hawaiian PRSV isolates $(5,14)$. This age-dependent susceptibility of Rainbow, which is hemizygous for the coat protein transgene, could explain our observation of field infection of Rainbow.

This observation suggests the need to constantly survey Hawaiian PRSV strains for their ability to overcome the transgenic resistance of Rainbow and SunUp. Further experiments are underway to critically determine the growth stages of Rainbow that are most susceptible to PRSV isolates from Hawaii. This information will be useful in developing integrative strategies for commercially growing Rainbow and SunUp. Fortunately, we have not yet observed breakdown of resistance in Rainbow and SunUp in commercial plantings, some of which are more than 2 years old. 
Table 1. Marketable yield and quality of transgenic and nontransgenic papaya lines homozygous and hemizygous for the coat protein transgene in the replicated field trial

\begin{tabular}{|c|c|c|c|c|c|c|}
\hline \multirow{2}{*}{$\begin{array}{l}\text { Yield or quality } \\
\text { character }\end{array}$} & \multirow[b]{2}{*}{ Treatment } & \multicolumn{5}{|c|}{ Harvest date } \\
\hline & & $1 / 97$ & $3 / 97$ & $5 / 97$ & $7 / 97$ & $12 / 97$ \\
\hline $\begin{array}{l}\text { Total fruit yield } \\
(\mathrm{kg} / \mathrm{ha} / \mathrm{wk})\end{array}$ & $\begin{array}{l}\mathrm{SU}^{\mathrm{x}}(\mathrm{cp} / \mathrm{cp})^{\mathrm{y}} \\
\mathrm{SU}(\mathrm{cp} /+) \\
\mathrm{RB}(\mathrm{cp} /+) \\
63-1(\mathrm{cp} /+) \\
\mathrm{SS}(+/+) \\
\mathrm{SS} \times \mathrm{K}(+/+)\end{array}$ & $\begin{array}{r}1,463 \mathrm{a}^{\mathrm{z}} \\
1,879 \mathrm{a} \\
1,728 \mathrm{a} \\
1,704 \mathrm{a} \\
972 \mathrm{~b} \\
1,079 \mathrm{~b}\end{array}$ & $\begin{array}{r}1,757 \mathrm{~b} \\
1,872 \mathrm{~b} \\
1,944 \mathrm{~b} \\
2,371 \mathrm{a} \\
745 \mathrm{c} \\
809 \mathrm{c}\end{array}$ & $\begin{array}{r}2,181 \mathrm{a} \\
2,359 \mathrm{a} \\
1,844 \mathrm{~b} \\
1,997 \mathrm{~b} \\
400 \mathrm{c} \\
383 \mathrm{c}\end{array}$ & $\begin{array}{r}1,512 \mathrm{~b} \\
1,524 \mathrm{~b} \\
2,963 \mathrm{a} \\
1,618 \mathrm{~b} \\
439 \mathrm{~d} \\
800 \mathrm{c}\end{array}$ & $\begin{array}{r}1,209 \mathrm{~b} \\
842 \mathrm{~b} \\
1,735 \mathrm{a} \\
137 \mathrm{c} \\
105 \mathrm{~d} \\
170 \mathrm{c}\end{array}$ \\
\hline $\begin{array}{l}\text { Average fruit weight } \\
\text { (kg/fruit) }\end{array}$ & $\begin{array}{l}\text { SU (cp/cp) } \\
\text { SU (cp/+) } \\
\text { RB (cp/+) } \\
63-1(\mathrm{cp} /+) \\
\mathrm{SS}(+/+) \\
\mathrm{SS} \times \mathrm{K}(+/+)\end{array}$ & $\begin{array}{l}0.55 \mathrm{~b} \\
0.61 \mathrm{a} \\
0.64 \mathrm{a} \\
0.56 \mathrm{~b} \\
0.55 \mathrm{~b} \\
0.64 \mathrm{a}\end{array}$ & $\begin{array}{l}0.63 \mathrm{~b} \\
0.64 \mathrm{~b} \\
0.75 \mathrm{a} \\
0.57 \mathrm{~b} \\
0.57 \mathrm{~b} \\
0.69 \mathrm{a}\end{array}$ & $\begin{array}{l}0.60 \mathrm{~b} \\
0.63 \mathrm{~b} \\
0.79 \mathrm{a} \\
0.57 \mathrm{~b} \\
0.59 \mathrm{~b} \\
0.78 \mathrm{a}\end{array}$ & $\begin{array}{l}0.62 \mathrm{~b} \\
0.61 \mathrm{~b} \\
0.82 \mathrm{a} \\
0.58 \mathrm{~b} \\
0.62 \mathrm{~b} \\
0.81 \mathrm{a}\end{array}$ & $\begin{array}{l}0.59 \mathrm{~b} \\
0.59 \mathrm{~b} \\
0.81 \mathrm{a} \\
0.60 \mathrm{~b} \\
0.59 \mathrm{~b} \\
0.79 \mathrm{a}\end{array}$ \\
\hline $\begin{array}{l}\text { Refractometer } \\
\text { solids }(\%)\end{array}$ & $\begin{array}{l}\mathrm{SU}(\mathrm{cp} / \mathrm{cp}) \\
\mathrm{SU}(\mathrm{cp} /+) \\
\mathrm{RB}(\mathrm{cp} /+) \\
63-1(\mathrm{cp} /+) \\
\mathrm{SS}(+/+) \\
\mathrm{SS} \times \mathrm{K}(+/+)\end{array}$ & $\begin{array}{l}13.6 \mathrm{a} \\
13.7 \mathrm{a} \\
13.5 \mathrm{a} \\
13.8 \mathrm{a} \\
13.0 \mathrm{a} \\
13.5 \mathrm{a}\end{array}$ & $\begin{array}{l}14.1 \mathrm{a} \\
14.2 \mathrm{a} \\
13.8 \mathrm{a} \\
13.9 \mathrm{a} \\
12.1 \mathrm{~b} \\
12.1 \mathrm{~b}\end{array}$ & $\begin{array}{l}14.1 \mathrm{a} \\
13.9 \mathrm{a} \\
13.8 \mathrm{a} \\
13.7 \mathrm{a} \\
13.2 \mathrm{~b} \\
13.7 \mathrm{a}\end{array}$ & $\begin{array}{l}13.9 \mathrm{a} \\
14.2 \mathrm{a} \\
13.6 \mathrm{a} \\
13.4 \mathrm{a} \\
13.1 \mathrm{~b} \\
12.8 \mathrm{~b}\end{array}$ & $\begin{array}{l}13.7 \mathrm{a} \\
14.1 \mathrm{a} \\
13.7 \mathrm{a} \\
13.5 \mathrm{~b} \\
13.6 \mathrm{~b} \\
13.8 \mathrm{a}\end{array}$ \\
\hline
\end{tabular}

${ }^{\mathrm{x}} \mathrm{SU}=\mathrm{SunUp}, \mathrm{RB}=$ Rainbow, 63-1 = a second transformant line with the same transgene in Rainbow, SS $=$ Sunset, SS $\times \mathrm{K}=\mathrm{hybrid}$ of Sunset and Kapoho (nontransgenic equivalent of Rainbow).

${ }^{y} \mathrm{cp} / \mathrm{cp}=$ homozygous for coat protein transgene, $\mathrm{cp} /+=$ hemizygous for coat protein transgene, $+/+=$ coat protein transgene absent

${ }^{z}$ Mean values are significantly different at $P=0.05$ when adjacent letters are different, using Duncan's multiple range test.

Many steps need to be taken before a transgenic product is commercialized. These include development of the product, testing of the product under greenhouse and field conditions, having regulatory product approvals by APHIS, EPA, and FDA, and having a product acceptable to the industry. Rainbow and SunUp represent a successful transgenic product that was developed, tested and evaluated, deregulated, and licensed for commercial use. It is an example of the successful utilization of transgenic technology that dramatically rescued the Hawaiian papaya industry from devastation by PRSV.

Our efforts represent a culmination of about 12 years of work. We believe, as do others $(6,13)$, that transgenic coat protein resistance can be used to control PRSV in papaya, and to control other important virus diseases of other crops.

\section{ACKNOWLEDGMENT}

This research has been supported by USDA/CSREES Special Grant No. 59-5320-5-694 in "Tropical/Subtropical Agriculture Research."

\section{LITERATURE CITED}

1. Animal and Plant Health Inspection Service, USDA. 1999. Administrative instructions prescribing methods of vapor heat treatment. 7CFR 318.13-4b.
2. Clark, M. F., and Adams, A. N. 1977. Characteristics of the microplate method of enzyme linked immunosorbent assay for the detection of plant viruses. J. Gen. Virol. 34:475-483.

3. Ferreira, S. A., Pitz, K. Y., Manshardt, R., Zee, F., Fitch, M., and Gonsalves, D. 1997. Transgenic papaya controls papaya ringspot virus in Hawaii. (Abstr.) Phytopathology 87:S30.

4. Fitch, M. M. M., Manshardt, R. M., Gonsalves, D., Slightom, J. L., and Sanford, J. C. 1992. Virus resistant papaya derived from tissues bombarded with coat protein gene of papaya ringspot virus. Bio-Technology 10:14661472.

5. Gaskill, D. A., Ferreira, S. A., Pitz, K. Y., and Gonsalves, D. 1998. Age dependent resistance to papaya ringspot virus in hemizygous transgenic papaya. (Abstr.) Phytopathology 88:S31.

6. Gonsalves, D. 1998. Control of papaya ringspot virus in papaya: A case study. Annu. Rev. Phytopathol. 16:415-437.

7. Gonsalves, D., and Garnsey, S. M. 1989. Cross-protection techniques for control of plant virus diseases in the tropics. Plant Dis. 73:592-597.

8. Ling, K., Namba, S., Gonsalves, C., Slightom, J. L., and Gonsalves, D. 1991. Protection against detrimental effects of potyvirus infection in transgenic tobacco plants expressing the papaya ringspot virus coat protein gene. Bio-Technology 9:752-758.

9. Lius, S., Manshardt, R. M., Fitch, M. M. M., Slightom, J. L., Sanford, J. C., and Gonsalves, D. 1997. Pathogen-derived resistance pro- vides papaya with effective protection against papaya ringspot virus. Mol. Breed. 3:161-168.

10. Manshardt, R. M. 1998. 'UH Rainbow' papaya. Univ. Hawaii Coll. Trop. Agric. Hum. Resour. Germplasm G-1.

11. Martin, D. M. 2000. Statistics of Hawaiian Agriculture 1996. Hawaii Agricultural Statistics Service.

12. Ploetz, R. C., Zentmyer, G. A., Nishijima, W. T., Rohrbach, K. G., and Ohr, H. D., eds. 1994. Compendium of Tropical Fruit Diseases. American Phytopathological Society, St. Paul, MN.

13. Smith, H. A., Swaney, S. L., Parks, T. D., Wernsman, E. A., Dougherty, W. G. 1994. Transgenic plant virus resistance mediated by untranslatable sense RNAs: Expression, regulation, and fate of nonessential RNAs. Plant Cell 6:1441-1453.

14. Tennant, P., Fitch, M., Manshardt, R., Slightom, J., and Gonsalves, D. 1997. Resistance against papaya ringspot virus isolates in coat protein transgenic papaya is affected by transgene dosage and plant development. (Abstr.) Phytopathology 87:S96.

15. Tennant, P. F., Gonsalves, C., Ling, K.-S., Fitch, M., Manshardt, R., Slightom, J. L., and Gonsalves, D. 1994. Differential protection against papaya ringspot virus isolates in coat protein gene transgenic papaya and classically cross-protected papaya. Phytopathology 84:1359-1366.

16. Yeh, S.-D., and Gonsalves, D. 1984. Evaluation of induced mutants of papaya ringspot virus for control by cross protection. Phytopathology 74:1086-1091. 